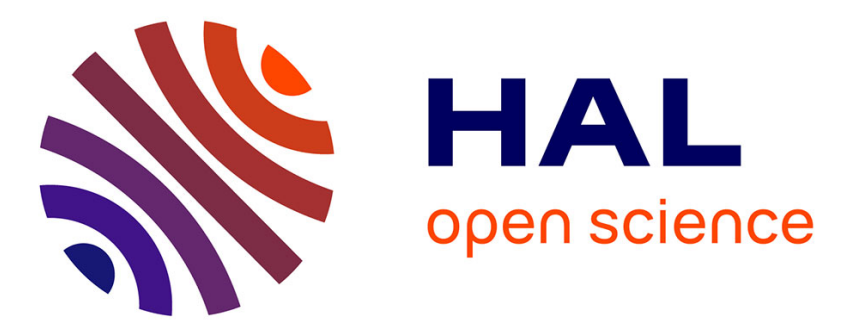

\title{
Haunted Island: Reflections on the Japanese Colonial Era in Taiwanese Cinema
}

\author{
Corrado Neri
}

\section{To cite this version:}

Corrado Neri. Haunted Island: Reflections on the Japanese Colonial Era in Taiwanese Cinema. William Morris. Japanese Taiwan: Colonial Rule and its contested Legacy, Bloomsbury, 2015. hal02278876

\section{HAL Id: hal-02278876 \\ https://univ-lyon3.hal.science/hal-02278876}

Submitted on 5 Sep 2019

HAL is a multi-disciplinary open access archive for the deposit and dissemination of scientific research documents, whether they are published or not. The documents may come from teaching and research institutions in France or abroad, or from public or private research centers.
L'archive ouverte pluridisciplinaire HAL, est destinée au dépôt et à la diffusion de documents scientifiques de niveau recherche, publiés ou non, émanant des établissements d'enseignement et de recherche français ou étrangers, des laboratoires publics ou privés. 


\section{Japanese Taiwan}

\section{Colonial Rule and Its Contested Legacy}

Edited by Andrew D. Morris

Bloomsbury Academic

An imprint of Bloomsbury Publishing Plc

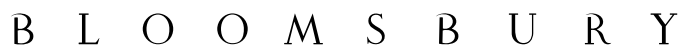

LONDON • NEW DELHI - NEW YORK - SYDNEY 


\title{
Bloomsbury Academic
}

An imprint of Bloomsbury Publishing Plc

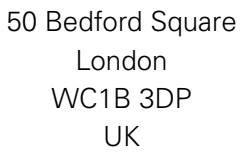

UK

\author{
1385 Broadway \\ New York \\ NY 10018 \\ USA
}

\section{www.bloomsbury.com \\ BLOOMSBURY and the Diana logo are trademarks of Bloomsbury Publishing PIc}

First published 2015

(c) Andrew Morris and Contributors, 2015

All rights reserved. No part of this publication may be reproduced or transmitted in any form or by any means, electronic or mechanical, including photocopying, recording, or any information storage or retrieval system, without prior permission in writing from the publishers.

No responsibility for loss caused to any individual or organization acting on or refraining from action as a result of the material in this publication can be accepted by Bloomsbury or the author.

\section{British Library Cataloguing-in-Publication Data}

A catalogue record for this book is available from the British Library.

\author{
ISBN: HB: 978-1-4725-7672-9 \\ ePDF: 978-1-4725-7673-6 \\ ePub: 978-1-4725-7674-3
}

\section{Library of Congress Cataloging-in-Publication Data}

A catalog record for this book is available from the Library of Congress.

\section{Series: SOAS Studies in Modern and Contemporary Japan}

Typeset by Integra Software Services Pvt. Ltd.

Printed and bound in Great Britain 


\section{Contents}

List of Illustrations

List of Tables viii

Notes on Contributors $\quad$ ix

Acknowledgments xii

Part 1 Making Japanese Taiwan

1 Andrew D. Morris, 'Introduction: Living as Left behind in

Postcolonial Taiwan' 3

2 Joseph R. Allen, 'Colonial Itineraries: Japanese Photography in Taiwan’ 25

3 Paul D. Barclay, 'Tangled up in Red: Textiles, Trading Posts, and the Emergence of Indigenous Modernity in Japanese Taiwan' 49

4 Scott Simon, 'Making Natives: Japan and the Creation of Indigenous Formosa' $\quad 75$

5 John R. Shepherd, 'Ethnicity, Mortality, and the Shinchiku (Xinzhu) Advantage in Colonial Taiwan’

Part 2 Remembering Japanese Taiwan

6 Evan N. Dawley, 'Closing a Colony: The Meanings of Japanese Deportation from Taiwan after World War II'

7 Chih Huei Huang, 'Ethnic Diversity, Two-Layered Colonization, and Complex Modern Taiwanese Attitudes toward Japan'

8 Andrew D. Morris, 'Oh Sadaharu/Wang Zhenzhi and the Possibility of Chineseness in 1960s Taiwan'

9 Corrado Neri, 'Haunted Island: Reflections on the Japanese Colonial Era in Taiwanese Cinema'

10 Jens Sejrup, 'Reliving the Past: The Narrative Themes of Repetition and Continuity in Japan-Taiwan News Coverage'

11 Marc L. Moskowitz, 'Drinking Modernity: Sexuality and the Sanitation of Space in Taiwan's Coffee Shops'

Glossary 


\section{List of Illustrations}

Figure 1.1 Wedding picture: Huang Cong (left) and Huang Shu

(Nakahara Masao, right), Taichū (Taizhong), 1937.

Photo courtesy of Ilon Huang

Figure 1.2 Taiwanese policeman Huang Shu (Nakahara Masao, right) and fellow officer, participating in flood rescue operation, Taikō (Dajia), around 1940. Huang/Nakahara was the commanding officer at the Citongiao police station on the outskirts of Shōka (Zhanghua). Photo courtesy of Ilon Huang

Figure 1.3 Huang Ba (Nakahara Torao), son of Officer Huang/ Nakahara in Figures 1.1 and 1.2. Nicknamed Tora (“Tiger”), Huang/Nakahara was the only Taiwanese student in his otherwise all-Japanese first-grade class, at Shōka (Zhanghua) Elementary School (Shōka jinjō kokumin shōgakkō), 1944. Photo courtesy of Ilon Huang

Figure 1.4 Zhanghua City Butokuden (Zhanghua shi wudedian). Photo by Andrew D. Morris

Figure 2.1 Meiji emperor (right) and his heir apparent (the future Taishō emperor), unlabeled opening photograph. Taiwan gun gaisen kinen shashinchō (1896)

Figure 2.2 Prince Kitashirakawa, military commander of the 1895 expedition, part of the portrait gallery. Taiwan gun gaisen kinen shashinchō (1896)

Figure 2.3 Prince Kitashirakawa encamped on arrival to Taiwan, May 29, 1895. Taiwan meisho fūzoku shashinchō (1903)

Figure 2.4 Airplane and pilots for the Musha (Wushe) expedition of 1930. Musha tōbatsu shashinchō (1931)

Figure 2.5 Leftmost two photos of montage of Japanese violence against Giran (Yilan) Aboriginal people, prisoners and beheading. Tōbatsu guntai kinen shashinchō (1913)

Figure 2.6 Taihoku (Taipei) street scenes ca. 1895. Taiwan gun gaisen kinen shashinchō (1896) 
Figure 2.7 Before (bottom) and after (top) photographs of downtown Taihoku commercial district street renovations. Taihoku shiku kaihen jinen shashinchō (1915)

Figure 2.8 Montage of Taipei city gates. Taiwan meisho shashinchō (1899)

Figure 2.9 Montage of new colonial buildings (clockwise from top left: weather observatory, hospital, pharmaceutical factory, post office). Taiwan meisho shashinchō (1899)

Figure 2.10 Taishō emperor and empress, opening page. Taiwan takushoku gachō (1918)

Figure 2.11 Lead photograph in "Snapshots of the Capital" section. Kamera de mita Taiwan (Lure of Taiwan), Vol. 3 (1937)

Figure 3.1 An Atayal couple with garments that display the use of imported dyed threads, buttons, and shells. The abundance of large shells on the man's cape and cap signify high social standing. In addition, he is wearing two government-issued badges that identify him as a "headman." Item wa0103, "Richly attired Atayal man and woman," East Asia Image Collection, Lafayette College

Figure 3.2 A diorama from the 1913 Osaka Colonial Exhibition with Atayal red-striped parkas prominently displayed as "The household of the Taiwanese Natives and its customs and manners." Item ip1472, "Grandcolonial Exhibition at Tennoji Park," East Asia Image Collection, Lafayette College

Figure 3.3 This photograph was taken by American journalist Harrison Forman in 1938, probably in Musha (Wushe). He titled it "Taiwan-woman weaving." While the ostensible subject of the photograph is native Atayal textile-manufacture, the photograph itself suggests that most Atayal people actually wore imported factory-produced clothing by this time. From the American Geographical Society Library, University of WisconsinMilwaukee Libraries. Harrison Forman Collection-Taiwan, American Geographical Society Digital Archive, Asia and Middle East (Milwaukee, WI: University of Wisconsin-Milwaukee), Digital ID: fr200018

Figure 4.1 General distribution map of Taiwan's Indigenous population. Courtesy of Wikimedia Commons

Figure 8.1 Oh puts on hitting demonstration at Taipei Municipal Stadium, December 7, 1965. Photo by Pan Yuekang, used with permission of Central News Agency (Zhongyang tongxunshe, Taiwan) 


\section{List of Tables}

Table 5.1 Crude death rates by ethnicity, all causes, 1906-1931.

Deaths per 100,000

Table 5.2 Cause-specific crude death rates by leading causes and by ethnicity and sex, 1906-1931. Deaths per 100,000

Table 5.3 Composition of prefectural populations by provenance, by percent of Taiwanese, 1920

Table 5.4 Distribution of the provenance groups among the prefectures, 1920

Table 5.5 Crude death rates by ethnicity and prefecture, 1920-1931 102

Table 5.6 Crude death rates by ethnicity and district, 1920-1931 105

Table 5.7 Sex ratios of mortality by ethnicity and district, 1920-1931. Male CDR/Fem. CDR 106

Table 5.8 Age-specific death rates, Hakka and Hoklo, Zhubei, 1906-1945. Deaths per 1,000 persons

Table 5.9 Life expectancy at different ages, Hakka and Hoklo, Zhubei, 1906-1945 


\section{Notes on Contributors}

Joseph R. Allen is Professor of Chinese Literature and Cultural Studies and Chair of the Department of Asian Languages and Literatures, University of Minnesota. He has held a National Endowment for the Humanities Fellowship, two Fulbright Research Fellowships, and a Faculty Fellowship in the Humanities at Harvard University. Trained in classical Chinese poetry, his early work included In the Voice of Others: Chinese Music Bureau Poetry (University of Michigan Center for Chinese Studies, 1992). He has focused on Taiwan and cultural studies in his recent works, including "Picturing Gentlemen: Japanese Portrait Photography in Colonial Taiwan" (Journal of Asian Studies, 2014) and Taipei: City of Displacements (University of Washington Press, 2012), and he is winner of the 2014 Joseph Levenson Book Prize in Chinese Studies, Post-1900.

Paul D. Barclay is Associate Professor and Chair of the Asian Studies Program at Lafayette College, and General Editor of the East Asia Image Collections Digital Archive. He has published articles in Journal of Asian Studies, Japanese Studies, Taiwan Genjümin Kenkyū (Studies on Indigenous Peoples of Taiwan), Humanities Research, and Social Science Japan Journal. He is a recipient of awards from the National Endowment for the Humanities, Social Science Research Council, Taiwan Ministry of Foreign Affairs, and the Japan Society for the Promotion of Science.

Evan Dawley is Assistant Professor of History at Goucher College. After completing a Ph.D. in Chinese History at Harvard, he worked for several years as a historian with the U.S. Department of State. He has also taught at Reed College, the George Washington University, and Georgetown University. He coedited, with Tosh Minohara and Tze-ki Hon, The Decade of the Great War: Japan and the Wider World in the 1910s (Brill, 2014). He is currently working on a book manuscript about the construction of Taiwanese ethnic consciousness in the port city of Jilong from the 1880 s to the 1950 s.

Chih Huei Huang is an anthropologist at the Institute of Ethnology, Academia Sinica, in Taiwan, and has conducted extensive fieldwork in Japan. Since 1995, she has translated a series of early-twentieth-century reports on the customs of Formosan Indigenous Peoples completed by the Japanese Governor-General's Office, and has published several papers in Japanese and Chinese on the postcolonial situation and ethnic relationship between Okinawa and Taiwan. Her interests also include the reestablishment of Taiwan-Japan relations and translating academic knowledge into legal action to support Indigenous rights and culture. Her chapter in this volume, 
presented in an earlier version, won the Best Paper Award at the first Asia Future Conference (Bangkok, 2013).

Andrew D. Morris is Professor of History at California Polytechnic State University, San Luis Obispo. He is the author of Colonial Project, National Game: A History of Baseball in Taiwan (University of California Press, 2010), Marrow of the Nation: A History of Sport and Physical Culture in Republican China (University of California Press, 2004), and coeditor (with David K. Jordan and Marc L. Moskowitz) of The Minor Arts of Daily Life: Popular Culture in Taiwan (University of Hawai'i Press, 2004).

Marc L. Moskowitz is Associate Professor in the Department of Anthropology at the University of South Carolina. Focusing on the intersection between gender and popular culture in Chinese-speaking Asia, he is a recipient of the ACLS-NEH, Chiang Ching-Kuo, Fulbright, and Fulbright-Hays Awards. He is the author of Go Nation: Chinese Masculinities and the Game of Weiqi in China (University of California Press, 2013), Cries of Joy, Songs of Sorrow: Chinese Pop Music and its Cultural Connotations (University of Hawai'i Press, 2009), The Haunting Fetus: Abortion, Sexuality and the Spirit World in Taiwan (University of Hawai'i Press, 2001). He edited Popular Culture in Taiwan: Charismatic Modernity (Routledge, 2010) and co-edited (with David K. Jordan and Andrew D. Morris) The Minor Arts of Daily Life: Popular Culture in Taiwan (University of Hawai'i Press, 2004). He also has directed and produced the ethnographic films Dancing for the Dead: Funeral Strippers in Taiwan (2011) and Weiqi Wonders: Conversations About the Game of Go in China (2012).

Corrado Neri holds a doctorate in Chinese Film Studies from the University of Ca' Foscari, Venice, and the University of Lyon 3. He is now Assistant Professor at the Jean Moulin University, Lyon 3. He has conducted extensive research on Chinese cinema in Beijing and Taipei and published many book chapters and journal articles in English, French and Italian. He is author of Tsai Ming-liang (Cafoscarina, 2004) on the Taiwanese film director and Âges inquiets: Cinémas chinois, Une représentation de la jeunesse (Tigre de Papier, 2009). He co-edited (with Kirstie Gormley) the French/ English bilingual book Le Cinéma taïwanais/Taiwan Cinema (Asiexpo, 2009) and (with Florent Villard) Global Fences: Literatures, Limits, Borders (IETT, 2011).

Jens Sejrup is a postdoctoral research fellow at the Centre for East and SouthEast Asian Studies, Lund University, Sweden. A Japan specialist, he holds a Ph.D. in East Asian Studies as well as an M.A. in Japanese Studies from the University of Copenhagen. Jens has published several research articles and book chapters, including "Instrumentalized History and the Motif of Repetition in News Coverage of Japan-Taiwan Relations" (Pacific Affairs, winner of the 2014 EastAsiaNet Award for Best Academic Article) and "Awakening the Sufferers: Reflections on Public Relations, Activism, and Subalternity in Postcolonial Controversies between Taiwan and Japan" (Public Relations Inquiry, winner of the 2012 Young Scholar Award from the European Association of Taiwan Studies). Jens serves as a steering committee member of the Nordic Association for the Study of Contemporary Japanese Society. 
John R. Shepherd, Associate Professor of Anthropology at the University of Virginia, is the author of Statecraft and Political Economy on the Taiwan Frontier, 1600-1800 (Stanford, 1993) and Marriage and Mandatory Abortion among the 17thcentury Siraya (American Ethnological Society, 1995), and the co-editor of Death at the Opposite Ends of the Eurasian Continent: Mortality Trends in Taiwan and the Netherlands, 1850-1945 (Aksant, 2011). Shepherd is currently engaged in research on the mortality transition in late-nineteenth- and early-twentieth-century Taiwan, the 1918 influenza epidemic in East Asia, and the practice of footbinding in Taiwan.

Scott Simon is Professor in the School of Sociological and Anthropological Studies and Research Chair in Taiwan Studies at the University of Ottawa. He specializes in the political anthropology of indigeneity and development in the Austronesian communities of Taiwan and is the author of the books Sadyaq balae! Lautochtonie formosane dans tous ses états (Presses de l'Université Laval, 2012), Tanners of Taiwan: Life Strategies and National Culture (Westview Press, 2005), and Sweet and Sour: Life Worlds of Taipei Women Entrepreneurs (Rowman \& Littlefield, 2003). 


\section{Acknowledgments}

This volume originated in a conference on "East Asian Dialogues: The Cultural Flow between Taiwan and Japan," organized by Marc Moskowitz at the University of South Carolina in February 2010. We are grateful to Gordon Smith, Director of the USC Walker Institute of International and Area Studies, and Dean Kinzley, Associate Director of the Walker Institute and Director of the USC Center of Asian Studies, for having made funding for this conference possible.

We would also like to thank Mark Selden, Leo Ching, Jennifer Liu, and several anonymous reviewers for their constructive input into this volume, and Eriko Takamine for her help with copyediting. We are also grateful to series editor Christopher Gerteis and Bloomsbury editorial assistant Emma Goode for their good cheer and their willingness to include the history of Japanese Taiwan in this exciting new SOAS Studies in Modern and Contemporary Japan series.

Finally, I would like to thank my wife Ricky, my daughter Shaina, and my son Aaron for their love and support as I edited this volume and always.

-Andrew D. Morris 


\title{
Haunted Island: Reflections on the Japanese Colonial Era in Taiwanese Cinema
}

\author{
Corrado Neri
}

\section{The colony}

The year 1895 was a pivotal year for the history of Asia and the history of arts: while in France the first public projection of the "cinématographe" was going to change forever the notions of realism and narration, the Treaty of Shimonoseki sealed Taiwan's fate of becoming the first Japanese colony. The cinema is stammering, groping, and hesitating, but soon turns out to be a powerful weapon of propaganda and indoctrination. At the same time, the films are incredible windows opened to the world: for the Taiwanese, they represent the opportunity to discover both the "Western" and the Japanese civilization-the two cultures that are starting to reshape the island, its identity, its politics, and its everyday life, as well. Stimulated by the Japanese government, Taipei becomes a modern capital, equipped with movie halls-as well as theaters, dance halls, modern transports, and electric lights.

Yet, the local cinematographic production stays underdeveloped. Perhaps because of its mostly decentralized geographical position, Taiwan will never become the center of cinematographic production as can be said about Manchuria-the predominant source of cross-border pan-Asian imagery. This does not prevent the colonial government from supporting the distribution and projection of Japanese films, as well as the typical aspects of the Japanese cinematographic culture, like benshi and rensageki, for example, in Taiwan. The term benshi refers to a person who sits near the screen in the dark auditorium, reads and translates the subtitles interpreting their content, explains the history of the film, comments on the images, and, in a postmodern manner far ahead of its time, also talks about the means of production, the camera, the ways the films were made, and the actors who play in them. A benshi can become a star, with his name listed on the posters in fonts larger than the names of the actors; yet, although the profession seemed destined to vanish, we can still find artists who perform this art in the cultural manifestations linked to the silent film. Rensageki is another hybrid form which brings live performance and the "true" cinema together: the actors play out the scenes of the film in front of the camera that records it, and afterwards during the projection, they are on the scene 
giving voice to their characters and connecting the sequences (Baskett 2008). Even though the import of Japanese films is very significant, many works keep arriving from China until the 1930s, tolerated by the colonial administration. The influence of the Chinese civilization on Taiwanese intelligentsia is still very strong, although a bit washed-out at the beginning of the twentieth century. The 1920s are a liberal and cosmopolitan period, at least for the elite who can travel relatively freely, and have the means to enjoy the exuberance of the urban and cultural life, while taking advantage of the seemingly infallible economic expansion.

For the Japanese producers, Taiwan is a perfect place for films like The Braves of Mount Ali (Arisan no kyoji, dir. Tasaka 1927), aimed both at the internal Japanese market and the utopian pan-Asian market. As Wafa Ghermani explains,

For the Japanese, the films made in Taiwan were the means to let city residents and the locals discover the new colony, with its wild side (the aboriginals) and the benefits of colonization. The fiction films, produced with the Taiwanese financial contributions, but made by the Japanese crew, were always under close surveillance. (2009a: 21)

The descriptions of Taiwan are at the same time orientalist and exotic-the land of savages, mysterious rituals, tribal dances, and diseases caused by the tropical climate. Moreover, the films are also suitable means of propaganda focusing on the creation of an Asian community guided by Japan, the source of civilization. Japan represents itself as a shield against Western invasion, wishing to be a modern industrialized country, and-as the newsreels, vastly spreading in schools and public places in the motherland, as well as in the colonies, testify-it is the only Asian country whose military defeated a Western country (Russia during their 1904-1905 war). Many educational films are made in $16 \mathrm{~mm}$ format-and shot in Japanese. These films are unfortunately lost; according to the descriptions in the written sources, these were geographic or animal documentaries about the "intact" nature of the island, the ethnographic films about the traditions of its inhabitants, as well as reports about the activities of the Japanese government in Taiwan. Many descriptions are ideologically marked by evocating the benefits of Japanization: industrial development, modernity of the cosmopolitan life of Taipei, and so on. The colonizer is portrayed as benevolent and paternalistic: educators, doctors, police officers, and soldiers exert their authority firmly and righteously, assisted by the cooperation of local inhabitants.

Yet, the situation changes in the 1930s, as the tension between Japan and China intensifies. After the Manchuria Incident of 1931 and the 1932 bombing of Shanghai, the majority of films made in the Republic of China are more and more openly anti-Japanese. Japanese censorship operates on two fronts: eliminating conflicting images likely to link Taiwan to the mainland and creating new ones that serve the political agenda now leaning toward ultra-nationalism. From the 1930s on, the Japanese propaganda becomes more powerful and aims at making its colonies part of the Japanese empire, suppressing the local identities and idealizing the civilizing role of Japan. Local languages are forbidden in public places, classes at schools are taught in Japanese, the altar for worshiping kamis is placed in homes, and members 
of the elite have to adopt a Japanese name. This politics called kōminka is officially imposed in Taiwan in 1937, when the conflicts with China escalate, introducing the "imperialization" of colonial subjects, their forced assimilation within the Greater East Asia Co-Prosperity Sphere. Still marked by a strong anti-Western sentiment, the government demands the subjects of the emperor to enroll in the army and fight for Japan, awarding them the right to die for the ruler. One of the most frequent themes in Taiwanese literature (written in Japanese and Chinese language) is this desire, contradictory and unfulfilled, to become a "true" Japanese, the loyal subject of the emperor. ${ }^{1}$ The cinema is used, along with science, as a weapon of propaganda and education. In 1941, the Taiwanese Cinematographic Association (Eiga kyōkai) joins the Taiwanese Educational Society (Kyōikukai), which was founded by the government to promote Japanese culture in Taiwan: cinema, like all other forms of expression, cannot ignore World War II anymore. During the 1930s, the Taiwanese students are shown the most famous places in Japan, they learn the national anthem, watch the cherry blossoms-and thereby already begins to spread the aestheticization of death in the battle which will become the leitmotiv of the recruitment imposed during the last years of the Pacific war (OhnukiThierney 2002). Pirates of the Seas (Umi no gözoku, dir. Arai 1942), for example, is set in the seventeenth century and tells the story of the Asian battle (the Japanese based in Taiwan) against the Dutch for the supremacy over the seas.

Sayon's Bell (Sayon no kane, dir. Shimizu 1943) is probably the most representative film, showing the efforts of militarization and Japanization. It is supposedly inspired by a true story, according to the propaganda. Sayon, a young Indigenous girl, is especially attached to her teacher, educated in Japan, who is leaving to go to war against China. Sayon supports him, and accompanies him in the pouring rain; yet, after shouting the last "Banzai!" she falls into the river and drowns. The imperial government erects a bell in the young girl's native village to honor the spirit and the devotion of the martyr. The idealistic representation of the Pax Nipponica is obvious: everyone-including the villagers-speaks Japanese flawlessly. All of the big symbols of the imperialist culture are there: Japan is manly and warlike (that is the place where one learns to fight), and the colony is feminine and in need of protection. The role of Sayon, the ideal colonial subject, is played by Yamaguchi Yoshiko, aka Li Xianglan/Ri Koran. ${ }^{2}$ In the film Sayon's Bell peasant values (solidarity, the central importance of the community and the family) are particularly emphasized. The villagers, although perfectly mastering the language of the colonizer, are represented performing their strange apotropaic and primitive dances. The gaze of the camera records, in a documentary manner, the primitive traditions of the locals-their clothes in high colors, the stubbornly highlighted lack of shoes, and the distant awe exhibited during the flag-raising ceremony. This film is dedicated to the patriotism and civilized transformation of the loyal subjects, to the regional government and to the devoted police officers.

Sayon's Bell was evoked/parodied decades later in Island Etude (Lianxi qu, dir. Chen 2006), a film that tells the story of a young man who travels around Taiwan on a bicycle, describes the people he meets on his journey, and offers a dreamlike episode evoking this chapter of Japanese legacy. First, the young protagonist stops 
to look at a group of tourists who are admiring the bell of Sayon, while listening to the explanations of their guide. Then, without interruption, a dreamlike sequence unfolds: asleep, the main actor dreams of a remake of the episode of the film from 1943. Illuminated by the bluish beams of light, a young girl accompanies the soldiers going to the front; the atmosphere remains serene, seductive, and mysterious. We are far from the portrait of the Japanese soldier as a sadistic stereotype like the ones we could see in the propaganda films of the 1950s and 1960s. More and more frequently, the Japanese colonization is represented, in the 1990s and 2000, like a politics that left a positive cultural heritage; this contributed to reinforcing an assumed originality of the Taiwanese identity (precisely mixed and multicultural) as opposed to continental China-more and more influential in Asia and in general in the global geopolitical arena on the economic front and, subsequently, on the cultural front.

In 2008, the National Museum of Taiwan History, located in Tainan, restored and published in DVD format a series of documentaries made by the Japanese during the colonial era. Even though the discourse of fiction films often represents Taiwan as a barbaric and backward society, these documentaries show, on the contrary, a modernized, rich, and multicultural colony. The colonial administration is proud to lead the countries that fall under its control out of "savagery" and underdevelopment in which they were immersed previously under Chinese/Manchu rule, claiming the duty to protect them from the influence of Western imperialism. Just like the much hated and resented Western powers did in their colonies, the Japanese shaped the industrial development and ways of communication, and established banks and post offices. The propaganda documentaries, rarely seen today, are mostly about convincing the subjects of the emperor (whether in Taiwan or in Japan) of the benefits of the colonization. Southward Expansion into Taiwan (Nanshin Taiwan 1935) outlines a tour of the island and revises the regime's technological achievements, especially dwelling on the modernization of industry and urbanism. The focus is also on the ancient and abandoned tradition of the binding of women's feet, emphasizing the evolution in customs-but also taking care to feature the local beauties and the legitimizing colonial phenomenon of cultural blending, with girls in qipao and ladies in kimono all walking down the street. In the first part of the film, an off-screen voice declares the following:

Because of population growth, Japan has exhausted its natural resources... we need to create a defense line in the South, and Taiwan is right there... Formosa is an important base for the expansion of the Empire towards the south. Therefore, we need to understand contemporary Taiwan in details. It is a rich island, bathed in sunlight and warmth, a source of wealth for Japan ... a dream island in the south ... Earlier, Taiwan had been regarded by the Qing Government as a wasteland with uncivilized inhabitants. But through the assimilation process the Japanese Government has succeeded in turning them into loyal subjects of the Empire.

Other documentaries, like Tainan Prefecture Civilian Dojo (Tainan-shū Kokumin dōjō 1943), for example, are about the proto-military training of the Taiwanese youth. 
Guided by severe Japanese discipline, the young Taiwanese spend an obligatory period in the barracks where they learn to march, handle weapons, pray to the kamis, honor the emperor, and endure the physical tests their trainers impose, such as taking a bath in the river we imagine to be frozen, involving in forced marches, and waking up at dawn. The young men also learn the language and lodestar principles of Japanese civilization. The last sequence, particularly impressive, shows the graduation ceremony. The young Taiwanese, impeccably lined in rows, salute the Japanese flag and pledge allegiance to the emperor:

These subjects are taking the oath to devote themselves to the holy war. Their devotion is evident in the ceremony: "I solemnly swear to offer my entire life to the Emperor; I am ready to sacrifice it for the great cause of establishing the Great Japanese Empire. I swear to undertake the meditation exercises, not to let my spirit wander, but to continually search for the knowledge of the world. After I quit the dojo, I will do my best to eradicate all the distracting thoughts in order to pursue my quest for knowledge."

Subsequently, they become the true "subjects of the Empire": stepping out of savagery, renouncing the status of the "primitive," entering the aristocracy of the imperial civilization. The 2008 restoration of these documentaries by the National Museum of Taiwan History reminds us that the colonial past is no longer suppressed-on the contrary, officially and scientifically debated in the public arena and even commodified into sophisticated souvenirs and novelties.

\section{The great masters revise the story}

After 1945, Taiwan "goes back" to China, even if, as we know, this was an ambiguous "return": the Qing dynasty that ceded the island to Japan does not exist anymore. Taiwan "returns" to its motherland, but the artificiality of expressing themselves in the official Japanese language (in the Taiwanese context) is replaced by the inauthenticity of expressing themselves in Mandarin. The key terms for understanding the cultural politics of Taiwan are "exile," "remembrance," and the "orphan syndrome." Exile is immediately associated with the separation from the motherland-and soon enough from the international community which recognizes the PRC as the rightful "China." Cultural memory is equally related to the land of the ancestors, where the tombs of the forefathers and the remains of the glorious historical past are located. As for the "orphan syndrome" (see Ma 2009), we can ask the following question: Do the Taiwanese feel more like the orphans of China or of Japan?

Taiwan certainly goes through social and political changes that bring it closer to a contemporary democratic system-an ideology that had already penetrated the Taiwanese collective imagination during the "Taishō democracy" era. Taiwan adopts a democratic system during the 1990s with the universal suffrage elections and the birth of several political parties. Non-Manichean narratives of Japanese domination start to spread from the 1990s; there are mentions of violence and 
deception of the colonial yoke, but at the same time, some films now also depict a nostalgic portrait of the remarkable figures of the Japanese administration, of the technical progress introduced by the colonizers, and the relationships of love or affections created between the two ethnic groups. See, for example, the very influential The Puppetmaster (Xi meng rensheng, dir. Hou 1993), where we can find both of these aspects as interconnected and complementary. One sequence shows the Japanese superintendents asking the male population to cut off their queue-a distinctive sign of identity and belonging to the Qing dynasty. The other episodes evoke how the master of puppets (the protagonist Li Tianlu) was able to survive during the war, that is, modifying his repertoire: discarding the traditional stories of the emperors, warriors, and concubines, and introducing the stories of heroic imperial soldiers who fight in the Pacific and die for the glory of Japan (in these episodes a change regarding language also takes place: Taiwanese is out and Japanese takes over). In the same film, upon evoking the departure of the colonizers, Hou films the sequences portraying the students in tears saying goodbye to their beloved Japanese professors.

In A Borrowed Life (Duosang, dir. Wu 1994), an autobiographic story of one of the main Taiwanese intellectuals (a screenwriter, novelist, and film director), the son has to confront his father who claims he belongs to the Japanese culture, calling himself Duosang, which is the Taiwanese (phonetic) version of the Japanese otosan ("father"). The father suffers after the end of the colonial period and does not accept the "restoration" of the "Chinese" governance; tragically, this shift makes him no longer attuned to the contemporary society or in unity with his children. This movie helps the contemporary public to develop a more nuanced view of history and its influence on lower-class workers, developing a complex discourse of intertwined emotions. The public can hardly relate to the stubborn, macho/patriarchal father figure, yet in the film clearly transpires a deep affection for the hard-working, silent, and frustrated Otōsan. It is hard to emit a clear-cut judgment (both on the nostalgia of the main protagonist and the lack of comprehension shown by his "modern" daughter, imbued with Chinese Nationalist education); it is precisely this ambiguity that gives its relevance to $A$ Borrowed Life (Chen 2008). If we consider that Wu is one of the most famous and influent voice of an "authentic" Taiwanese culture, this film resonates with further implications in the definition of a shifting "identity"-both personal and national.

Besides the contradictions related to different readings of history, it is particularly clear, in this film, that speaking about the heritage of Japanese domination means to speak about Taiwanese identity itself, notably in contrast with Mainland China. As Lu Tonglin has convincingly demonstrated,

Instead of serving as an external other against which national identity could be defined, colonial Japan offers a counterpoint to mainland China in the reformulation of Taiwanese identity, after four decades of the Nationalist Party's China-centered ideology, and Communist China's military threat of the 1990s. (Lu 2011: 765) 
The sympathetic description of Japanese culture is unique in Taiwan-compared to other former colonies. This is to be drawn to the confrontation with China but also, again following $\mathrm{Lu}$ Tonglin, to the Nationalist imposition of the four-decade-long martial law. $\mathrm{Lu}$ argues thus:

If nostalgia for the Japanese colonial period has a broader retrospective appeal among the Taiwanese of Duosang's generation than it has historically, ironically, this has more to do with the Nationalists' accusation of Taiwanese "enslavement" at the initial stage of their power than with the success of kominka, which was largely limited to the educated upper class. This partly explains why Taiwan is the only former colony in which this nostalgia is publicly professed. (Lu 2011: 767)

Duosang-and his generation-has been disempowered by the arrival of the Guomindang: his Japanese education became suddenly useless (or suspicious), and his poor Mandarin skills made him redundant in the ROC era. Drawing a parallelproposed by $\mathrm{Wu}$ himself-between his father and former president Lee Teng-hui, $\mathrm{Lu}$ argues that nostalgic representation of Japan is more than a deconstruction of nationalism or a cultural relativism. It is used instead as the image of the (missing) Other/Father in opposition to the pre-1987 (martial law-era) Nationalist Party and/or to the contemporary menacing political, economic, and cultural hegemony of China, an image of postideological consumerism as well as a politicization that declines different definition of local identities.

\section{Viva Tonal: The musical memory}

Numerous other texts recall the Japanese cultural heritage with sympathy and nostalgia. Several contemporary Taiwanese films show a problematic and ambiguous relationship with Japan, at the same time marked by nostalgia, reverie, and regret for the departure of the ancient colonizer. The documentary Viva Tonal, the Dance Age (Tiaowu shidai, directed by Chien Wei-su and Kuo Chen-ti [2003]) recounts the story about the spread of gramophones in Taiwan under occupation in the 1930s-1940s. The interviewees, old pop music stars, express themselves in a mixture of Mandarin, Taiwanese, and Japanese language; and often sing in the language of the former occupant, the language of their artistic glory, the language of the golden age of Taiwanese popular culture at the beginning of modernity. Viva Tonal was supported by the government and press and brought to public attention by former ROC president Lee Teng-hui (the DVD collector edition booklet features an appraising article by Lee). Can we say then that the Taiwanese represent themselves as deprived of a voice, or that this film-which was a big success, and was in the cinema for months, and then broadcast on TV and even available in video and book storesindicates a deprivation of voice? Or yet, does it portray the pleasure of speaking in 
a borrowed-and really fascinating - voice of the old colonizer? Aren't we facing a symbol of the specific Taiwanese identity (a hypothetical concept) which is erased in the name of the victorious and lamented model of the old occupier? In any case, the mixture of languages and cultures cited above relies, all in all, on a very positive vision of the colonial period. Even when they do not sing in Japanese, the aesthetic model comes straight from the Tokyoite craze of that period, about the popular culture (mainstream?) of the Western model, but reviewed and adapted to the Asian context.

\section{The paradigms of love}

We have already mentioned the quotation from Sayon's Bell (1943) in a sequence of Island Etude (2006). This film gives us the opportunity to evaluate the presence and persistence of a love paradigm between the two countries. Paradoxically, we could even say that Japan - as a social body, the myth of pan-Asian (post)modernity-stays (or imposes itself again as) the object of desire and nostalgia. These contemporary representations tackle different themes which express various modalities of the relationship to the other, where the other-Japan-ignites passions and often introduces new ways to love, and to relate to sexuality and love. More and more often Taiwan demonstrates the necessity to come back to its colonial history to find a solution for its isolation and make up for its losses; the nationalist (Japanese) and ideological (imperialist) approach of the colonial period was suppressed but resurges again.

In the first place, it is remarkable that in the two very recent films Miao Miao (dir. Cheng 2008) and Somewhere I Have Never Travelled (Dai wo qu yuanfang, dir. Fu 2009), a Japanese character is the trigger of the protagonist's awareness of his or her homosexuality (a young girl in the first, and a boy in the second film). The otherness arouses desire. The stranger, the one who is in transit, suggests the paths that were not explored before the encounter. If we adopt a political reading, we can equally observe the re-evaluation of a colonial relationship in these texts, a relationship which, in spite of the corrupt practices the Taiwanese were subjected to, shaped a kind of individual consciousness and a new relationship to the other which, in addition, moves away from China.

Love (with several parental/incestuous connotations) is inevitably reactivated in the relations of Taiwanese and Japanese characters who meet each other in these movies (we will quote later Cape No. 7); the search for a paternal figure who can confirm an identity implies a declaration of love, embodied in a pan-Asian relationship where Taiwan imagines the ancient colonizer as a lover, model, and passion. There are even several films that use the Japanese body as an erotic element. In Invitation Only (Jueming paidui, dir. Ko 2009) and The Wayward Cloud (Tianbian yi duo yun, dir. Tsai 2005), for example, Japanese AV actresses (Maria Ozawa and Yozakura Sumomo, respectively) are asked to show what Taiwanese actresses cannot or do not want to show. The Wayward Cloud is a porno-musical which plays with the codes of the cinema of the absurd to point out to the mechanization of desire in the contemporary society: the insatiable thirst for love and feelings that are temporarily relieved with the capitalist 
consumption of erotic representation. Invitation Only is the first Taiwanese attempt at a true "slasher" film, where the first girl who breaks the chastity taboo automatically becomes the first victim of the sadistic killer. Respecting the rules of the genre, the first victim of Invitation Only, Ozawa, is the first (and the only) girl to show her private parts shamelessly. In Invitation Only and The Wayward Cloud, the naked bodies of the actresses are exclusively Japanese. On the one hand, this simply reveals the Taiwanese interest (and more generally that of East Asia) for the very developed Japanese porn industry, particularly vivacious, and which, even if it has to juggle with the old codes of censorship, can allow itself to cross the borders of representability, impossible in other Asian countries. On the other hand, in the systematic use of the eroticized Japanese body in the Taiwanese movies, we can equally observe a sort of macho revenge that uses the feminine body of the ancient colonizer finally disposable as a sex tool. Or, in a Freudian manner, Japan is the fetishized body that legitimates an erotic passion otherwise (hypocritically) suppressed. Pornography is accepted if performed outside of its symbolical limits, coming from the outside-a representation that does not compromise the innocence and purity (of course, imaginary) of the national body. In any case, what is at stake here is a "ghostly" presence, a symbolical substitution of the suppressed elements of (the representation of) sexuality-displaced toward the available and visible body of the Japanese actresses.

We can suggest a meta-cinematographic reading, in which the presence of a Japanese actress is an allegory of the call for authority of the emblematic Japanese tradition. The choice of transferring and reducing the erotic impulses to a Japanese female actress indicates a strategy of legitimization on the part of the Taiwanese cinematographic industry, which has been in crisis for about fifteen years. The role of the young Japanese girl is used not only to break certain sexual taboos but also as tactics to demand a figure of paternal reference, Ozawa's ghostly presence remaining an allegoric sacrifice asking for blessing in the future production of Taiwanese film.

\section{Parenthesis: Taiwan in Japan}

We will make a small digression about Café Lumière (Kafei shiguang), Hou Hsiaohsien's (2003) tribute to Ozu Yasujiro. Invited to shoot a film in Tokyo to commemorate the 100th anniversary of Ozu's birth in 2003, the master of the Taiwanese cinema creates a story about a young Japanese girl who is impregnated by her Taiwanese lover (who is never shown); the baby's body indicates the hidden presence of Taiwan in the most everyday aspects of the contemporary Japanese life-the guilt and the need to get the old passion back, at the same time. Moreover, the young protagonist makes some inquiries about the Taiwanese composer Jiang Wenye, who worked in 1930s Tokyo as Kō Bunya and represented Japan in the Art Competition of the 1936 Berlin Olympics with his "Formosan Dance" (Taiwan bukyoku). We can here comment on Hou's hypothesis, inviting us to think about the underground influence of Taiwanese culture on Japan. Actually, connecting these two symbols of persistence and intimate alliance between the two countries (the baby of the Taiwanese father and the Taiwanese artist 
who works in Tokyo) to a presence of a very peculiar anachronism (which we will discuss in an instant), we can interpret the idea of the cultural transits. The relations between the two countries are less unidirectional than we are often inclined to believe. In fact, we have a tendency to describe the influence of the Japanese culture on Taiwan but we usually neglect to examine the relationship the other way around. The musician figure casts doubts on the dialogue between the two countries, on the possibility of the ongoing presence of cultures of the formerly colonized country in contemporary Japan. Furthermore, in an ambiguous ellipsis-asking the audience to actively engage in the interpretation of the film-Hou raises yet another suspicion. The young girl offers a souvenir from Taiwan to her boyfriend-a watch commemorating the 116th anniversary of the railway inauguration in Taiwan. As Shota Ogawa affirms, this means that the aforementioned railway track was built in 1887, eight years before the arrival of the Japanese on the island:

The eight-year lapse between the railway opening and the Japanese colonization of Taiwan demands us to reconsider the oft-made association between Taiwan's colonial history and technology and institutions of modernity ... Through the 8-year lapse between 1887 and 1895, Hou questions a closed notion of history as a linear progression formed by a series of causal effect relations and demands an understanding of cinema as a modern institution that ambivalently empowers the state as well as the masses ... Café Lumiere quietly but evocatively imbues the contemporary images of Tokyo with the traces of multicultural reality on which both Japan and Taiwan are founded. (Ogawa 2009: 165)

This interpretation of history modifies the relationship between Japan and Taiwan. The two chronologies intertwine and stay penetrable and porous. Hou suggests an overlapping of the history of two countries; he does not assume the role of a historian, but of an artist, who goes on questioning and suggesting, rather than demonstrating. Inspired by the vision of Café Lumière, the audience can begin to investigate history and observe that, even though Japan kept the predominant role in this relationship, Taiwan in fact had a very visible influence on the social and cultural history of Japan.

\section{Conclusion}

The trend of "reconciliation"3 is a major current in Taiwan since the end of the 2000s. Blue Brave: The Legend of Formosa in 1895 (1895, dir. Hung 2008) evokes the Taiwanese Hakka resistance to the Japanese troops who arrive in 1895 to claim their first colony and their subsequent efforts to fight for the independence of their new Republic of Taiwan. It predictably glorifies the deeds of the warriors, but the only offscreen voice-which allows us to enter the intimacy of the first person-is Japanese, incarnated here in the historical figure of a writer, Mori Ōgai, who was sent off to Taiwan to be an army doctor. During the entire movie, the only voice that we hear in the first person is exclusively Japanese. That is, the only subject who truly can 
express himself is Japanese. Even though Taiwanese characters make conversation throughout the entire movie, the character of Mori Ōgai is the only one to express his individuality via the intimacy of a diary, and with pacifistic and profoundly humanistic comments. In the final sequence, he is the only one who has the privilege and the right to speak, and to regret the war, exclaiming with regard to the victory of the Japanese repression over the local resistance, "there is nothing to be proud of in a victory; there should be a funeral march instead of a celebration." Although he certainly does not represent democracy, Mori Ögai might as well be the voice of individuality with which the Taiwanese characters are never able to speak.

But why don't the Taiwanese speak in this film, which after all is supposed to represent them and portray their fight for independence? More precisely, they do talk, but only through dialogue; the only one to have the privilege to engage in a monologue, and thereby express the individual emotions and thoughts, under the projector, without sharing the scene with anyone, is the Japanese intellectual. In a discussion about this subject, Professor Chiang Shu-Chen maintains that this gives the audience the unique opportunity to identify with Mori Ōgai's implicitly pacifistic character (personal communication, June 2010). To pin down the accuracy of this representation of the writer is a particular difficult task, since Mori Ögai was a greatly influential writer as well as a public/official figure. The contradiction of being an army officer and a Westernized humanistic intellectual compels Lorenzo Costantini, who depicts Mori as a libertarian and a "paternalist and illuminated conservative" (1994). Mori defended the freedom of press when, at the end of Meiji, repression and censorship were increasing; but he always was a strong upholder of Confucian traditional values and morality; he criticized despotism but also praised the imperial army for its discipline, values, and spirit of sacrifice; he contributed to modernizing and Occidentalizing Japanese literature but ended his literary career rewriting stories of feudal Japan; he was a rational intellectual influenced by Western philosophy, but at the same time defended the Confucian, socially relevant figure of the intellectual.

Mori's characterization in 1895 could be accurate but mainly it is embedded in the contemporary reconciliation strategy that, in my view, tends to "shift" Taiwan away from China and toward Japan. This agenda is by no means accepted by all Taiwanese; still, the examples here have a telling frequency to portray the Japanese invaders in a civilized, positive way-an impossibility in PRC filmography. Mori depicts the ideal modern and independent intellectual, still moved by "traditional" aesthetics but committed to a benevolent colonial position. Which begs the question: why use a Japanese character as an instrument of engaging the public in the story? And why give him explicitly this aura of wisdom and exemplary nature? Is the Taiwanese public supposed to identify more easily with a Japanese intellectual, rather than a Hakka militant?

Cape No. 7 (Haijiao qi hao, dir. Wei 2008), tells a twofold love story in chiasmus. In the narrative a Taiwanese rock musician falls in love with a Japanese girl; in flashback sequences the love story depicts a Japanese teacher, who has to leave Taiwan in 1945, leaving behind a young Taiwanese woman in mourning. The film is punctuated by the unsent letters of the young man, who-again-is the only one 
to talk in first person, in an intense and poetic monologue. As in Blue Brave, this Japanese protagonist is the only one who has the right to speak, the right to represent his individuality, and the power to "start a speech." The voice heard in the beginning and in the end of the film (under the flag of Retrocession") is not a "free" or "freed" voice of the Taiwanese people but a romantic, imperialist, seductive, and idealistic voice of Japan. We should also mention the sequence that marks the culmination of the love story at present: the young Taiwanese singer finally decides to reveal his feelings for the Japanese girl, and whisper to her on the beach at sunset: "stay; or otherwise I'll come with you." If we read this episode from a "political" perspective, in which the Taiwanese boy allegorizes Taiwan and the Japanese girl represents Japan, we can hear a cry advocating the comeback of a poor orphan under the Japanese domination. If we overlook the "sentimental" character of this mainstream film, we can easily find a political parable that suggests an overdetermination of feelings, as if these individuals were obliged to reactivate their colonized/colonizer relationship, and to do it with passion. What is in question here-is this the reactivation of a new love relationship or a parental one?

Cape No. 7 was the most successful Taiwanese film ever. The "avatar" of the local production is a voice that does not express itself either in Mandarin or in Taiwanese but quite obviously in Japanese. Isn't the idea of the Taiwanese individual-also, of course, as a reaction to the fear of the PRC superpower which threatens to swallow it up in its one-party system-more and more oriented toward the Pacific, and consequently toward Japan? The Taiwanese citizen/subject is increasingly imagined without a voice, deprived of voice, or more accurately, as the orphan of Japanese expression, of authenticity, poetry, and power of the Japanese language. This attempt to redefine national identity is a compromise between the search for the roots and the need for independence: in any case, it is a centrifugal force aiming to move the Taiwanese identity away from China, and consequently, to draw it closer to Japan. It is important to underline that Cape No. 7 has not been an isolated case; Wei Tesheng continued to explore the history of Taiwan with Warriors of the Rainbow: Seediq Bale (Saideke Balai, dir. Wei 2011) and KANO (prod. Wei; dir. Umin 2014). Warriors is set in the 1930s during the bloody Seediq-led Musha uprising against the Japanese; while the colonial power suppresses the revolt, the winning general shows great respect for the Aboriginal adversary: he is surprised to find on a lost island in the middle of the Pacific the long-lost spirit of Bushidō. Set at the same early 1930s moment, KANO is a baseball drama that features an ethnically mixed high school team (Japanese-Taiwanese-Aboriginal) that, under the inflexible but inspiring coaching of a Japanese retired champion, manages to represent Taiwan at the Kōshien championships in the home islands. They will not win, but will earn the respect of the spectators (who overcome their initial prejudices) by displaying a true sporting spirit-competition, self-surpassing, honor. The final sequence is a reverse shot of the beginning of Cape No. 7 , showing the team on the boat coming "home" to Taiwan after having earned the admiration of the Japanese motherland. $K A N O$, a commercial success, also already has shaped the public debate-even if the director and producers refrain from giving overtly political interpretationover Taiwan's Japanese and Chinese heritage. 
For Taiwan-a sovereign nation with great resources but still diplomatically isolated and constantly threatened by the rise of the PRC-Japan could represent a guide or, in any case, an image of power to which it is ideologically, politically, and socially attached, or so these movies seem to suggest. It has to be indicated that Taiwan is a plurivocal place where not everyone shares this craze for Japan I have just reported; other voices, on the contrary, revive the memory of the injustices suffered during the colonial era. What seems interesting to analyze here is this particular form of representation, indirectly very positive, of the Japanese culture as a model (besides the globalized craze for anime, manga, J-Pop), as a space of liberty, a trigger of the nonconfessed desires, and an inspiration. It is a form of oblique and nuanced representation and a source of interpretation that expresses itself in an increasingly powerful voice within mainstream Taiwanese cinema and which, consequently, seems to reject the possibility of a menacing Chinese "reunification" in the future, orienting itself rather toward Japan-a Japan certainly imaginary, yet present in the collective subconscious. It is definitely not the case for all Taiwanese, this goes without saying; but I seem to hear a cry coming from Taiwan more and more often, and more and more powerfully, a nostalgic longing, with a maybe slightly masochistic trait, which informs us about the fear of PRC authoritarianism, but of the idleness of democracy, as well. A cry that says, "Give me back my colonizer!”

\section{Notes}

1 The most relevant reference is Wu Chuo-liu's 1945 novel The Orphan of Asia (Yaxiya de gu'er); he describes the psychological struggles of a Taiwanese intellectual growing up under Japanese rule, writing about self, national identity, and the anxiety of colonial consciousness.

2 A compelling novelization of Yamaguchi's life and influence on Asian culture could be found in Buruma (2008).

3 I am thankful to National Taiwan University Professor Sebastian Liao for his enlightening discussions of this subject.

4 For more on the concept of Retrocession (Guangfu), see Ghermani (2009b). 
